\title{
Coxiella-like bacteria in fowl ticks from Thailand
}

\author{
Wachareeporn Trinachartvanit', Simaporn Maneewong ', Warissara Kaenkan', Pawiga Usananan?', \\ Visut Baimai $^{1,2}$ and Arunee Ahantarig ${ }^{1,2^{*}}$
}

\begin{abstract}
Background: Coxiella bacteria were identified from various tick species across the world. Q fever is a zoonotic disease caused by the bacteria Coxiella burnetii that most commonly infects a variety of mammals. Non-mammalian hosts, such as birds, have also been reported to be infected with the pathogenic form of "Candidatus Coxiella avium". This research increases the list of tick species that have been found with Coxiella-like bacteria in Thailand.

Methods: A total of 69 ticks were collected from 27 domestic fowl (Gallus gallus domesticus), 2 jungle fowl (Gallus gallus) and 3 Siamese firebacks (Lophura diardi) at 10 locations (provinces) in Thailand. Ticks were identified and PCR was used to amplify Coxiella bacteria 165 rRNA, groEL and rpoB genes from the extracted tick DNA. MEGA6 was used to construct phylogenetic trees via a Maximum Likelihood method.

Results: The phylogenetic analysis based on the 16S rRNA gene showed that the Coxiella sequences detected in this study grouped in the same clade with Coxiella sequences from the same tick genus (or species) reported previously. In contrast, rpoB gene of the Coxiella bacteria detected in this study did not cluster together with the same tick genus reported previously. Instead, they clustered by geographical distribution (Thai cluster and Malaysian cluster). In addition, phylogenetic analysis of the groEL gene (the chaperonin family) showed that all Coxiella bacteria found in this study were grouped in the same clade (three sister groups).

Conclusions: To our knowledge, we found for the first time rpoB genes of Coxiella-like bacteria in Haemaphysalis wellingtoni ticks forming two distinct clades by phylogenetic analysis. This may be indicative of a horizontal gene transfer event.
\end{abstract}

Keywords: Coxiella-like bacteria, Fowl ticks, Thailand

\section{Background}

Ticks are ectoparasites of vertebrates transmitting pathogens like protozoa, viruses and bacteria which cause zoonotic diseases in domestic animals and humans. Both hard and soft tick species have been documented to harbour Coxiella bacteria. For example, the soft ticks Ornithodoros capensis (s.l.), O. rostratus and the hard ticks Dermacentor atrosignatus and Amblyomma testudinarium have been found to be infected with Coxiella bacteria [1-4].

$\mathrm{Q}$ fever (Query fever) is a zoonotic disease caused by Coxiella burnetii that most commonly infects a variety

\footnotetext{
* Correspondence: arunee.aha@mahidol.ac.th

${ }^{1}$ Biodiversity Research Cluster, Department of Biology, Faculty of Science, Mahidol University, Rama 6 Road, Bangkok 10400, Thailand

${ }^{2}$ Center of Excellence for Vectors and Vector-Borne Diseases, Faculty of

Science, Mahidol University at Salaya, Phutthamonthon 4 Road, Nakhon

Pathom 73170, Thailand
}

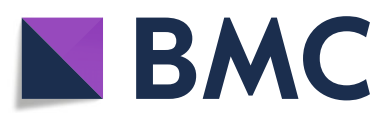

(c) The Author(s). 2018 Open Access This article is distributed under the terms of the Creative Commons Attribution 4.0 International License (http://creativecommons.org/licenses/by/4.0/), which permits unrestricted use, distribution, and

reproduction in any medium, provided you give appropriate credit to the original author(s) and the source, provide a link to the Creative Commons license, and indicate if changes were made. The Creative Commons Public Domain Dedication waiver (http://creativecommons.org/publicdomain/zero/1.0/) applies to the data made available in this article, unless otherwise stated. affects the reproductive system in animals causing stillbirths and miscarriages. Infection of $C$. burnetii in humans results from inhalation of contaminated aerosols in nature or from direct contact with infected domestic animals products or formites $[5,6]$. Individuals infected with $C$. burnetii were detected among rice farmers who raised cattle and chickens in northeastern Thailand. A seroepidemiological survey of C. burnetii in cattle and chickens in Thailand was carried out using an indirect fluorescent antibody test. Only one out of 113 serum samples from fowl was seropositive [7]. Moreover, non-mammalian hosts, such as birds, have also been reported to be infected with "Candidatus Coxiella avium" [8]. 
Coxiella bacteria were identified from various species of Haemaphysalis and Rhipicephalus sanguineus (s.l.) ticks in Thailand [3, 9]. Nevertheless, in Thailand, infection of Coxiella bacteria in fowl ticks has rarely been investigated. Therefore, the aims of this work were to determine the presence of Coxiella bacteria in fowl ticks and to study their evolutionary relationships in phylogenetic analyses based on partial $16 \mathrm{~S}$, rров (RNA polymerase beta-subunit), and groEL (the chaperonin family) gene sequences.

\section{Methods}

\section{Tick samples and identification}

A total of 69 ticks were collected from 27 domestic fowl (Gallus gallus domesticus), 2 jungle fowl (Gallus gallus) and 3 Siamese firebacks (Lophura diardi) at 10 locations (provinces) in Thailand during 2014-2016: (i) Chaiyaphum; (ii) Chumphon; (iii) Krabi; (iv) Pattani; (v) Rayong; (vi) Satun; (vii) Songkhla; (viii) Surat Thani; (ix) Trang; and ( $\mathrm{x}$ ) Yala (Table 1). The ticks were removed by using forceps, stored in $70 \%$ alcohol and preserved at $-20{ }^{\circ} \mathrm{C}$ awaiting further identification and molecular assays. Ticks were classified by developmental stage and sex and identified based on morphology using standard identification keys [10, 11]. Ticks positive for Coxiella bacteria were also molecularly identified using a primer set consisting of $16 \mathrm{~S}+1$ and $16 \mathrm{~S}-1$ to detect tick $16 \mathrm{~S}$ mitochondrial DNA (16S mDNA) [12].

\section{DNA extraction from tick samples and PCR}

Ticks were washed with $70 \%$ ethanol and $10 \%$ sodium hypochlorite and rinsed three times with sterile distilled water. Then, ticks were immediately homogenized using the TissueLyser system (QiagenGmbH, Hilden , Germany). One 3-mm tungsten carbide bead (Qiagen $\mathrm{GmbH}$, Germany) was added to each tube (collection microtubes; Qiagen $\mathrm{GmbH}$, Germany) and ticks (individual for adult, individual for Amblyomma nymph and a pool of 5 for nymph of Haemaphysalis) were homogenized for $4 \mathrm{~min}$ at $30 \mathrm{~Hz}$. After a short centrifugation step ( $5 \mathrm{~s}$ at $3220 \times g)$, the supernatants were collected in separate collection microtubes and DNA extracted using Qiagen's DNeasy Blood and Tissues Kit (Qiagen GmbH, Germany) following the manufacturer's instructions. Genes and primers used to amplify Coxiella DNA were used as in a previously reported protocol [13].

Table 1 Tick samples from domestic fowl (Gallus gallus domesticus), jungle fowl (Gallus gallus) and Siamese fireback (Lophura diardi)

\begin{tabular}{|c|c|c|c|c|c|c|}
\hline \multirow{2}{*}{$\begin{array}{l}\text { Location } \\
\text { no. / Province }\end{array}$} & \multirow[t]{2}{*}{ No. of hosts } & \multicolumn{3}{|c|}{ No. of ticks tested } & \multirow[t]{2}{*}{ Tick species } & \multirow{2}{*}{$\begin{array}{l}\text { No. of ticks } \\
\text { positive for } \\
\text { Coxiella }\end{array}$} \\
\hline & & $M$ & $\mathrm{~F}$ & $N$ & & \\
\hline \multirow[t]{3}{*}{ 1. Chaiyaphum } & \multirow[t]{3}{*}{ Siamese fireback $(n=3)$} & 0 & 0 & 3 & A. testudinarium & $1 \mathrm{~N}$ \\
\hline & & 0 & 1 & 0 & H. wellingtoni & - \\
\hline & & 0 & 0 & 5 & H. obesa & $5 \mathrm{~N}$ \\
\hline 2. Chumphon & Domestic fowl $(n=2)$ & 1 & 2 & 0 & H. wellingtoni & $1 F$ \\
\hline \multirow[t]{2}{*}{ 3. Krabi } & \multirow[t]{2}{*}{ Domestic fowl $(n=3)$} & 3 & 2 & 0 & H. wellingtoni & $1 \mathrm{M}, 1 \mathrm{~F}$ \\
\hline & & 0 & 0 & 3 & H. bispinosa & $1 \mathrm{~N}$ \\
\hline 4. Rayong & Domestic fowl $(n=1)$ & 0 & 1 & 0 & H. wellingtoni & $1 F$ \\
\hline \multirow[t]{2}{*}{ 5. Satun } & \multirow[t]{2}{*}{ Domestic fowl $(n=5)$} & 5 & 4 & 0 & H. wellingtoni & $1 F$ \\
\hline & & 0 & 0 & 3 & H. wellingtoni & - \\
\hline 6. Trang & Domestic fowl $(n=2)$ & 0 & 2 & 0 & H. wellingtoni & $2 \mathrm{~F}$ \\
\hline \multirow[t]{3}{*}{ 7. Pattani } & \multirow{3}{*}{$\begin{array}{l}\text { Domestic fowl }(n=2) \\
\text { jungle fowl }(n=1)\end{array}$} & 0 & 2 & 0 & H. wellingtoni & - \\
\hline & & 5 & 6 & 0 & R. microplus & - \\
\hline & & 0 & 0 & 3 & H. wellingtoni & - \\
\hline 8. Songkhla & Domestic fowl $(n=9)$ & 7 & 4 & 0 & H. wellingtoni & - \\
\hline \multirow[t]{2}{*}{ 9. Surat Thani } & \multirow[t]{2}{*}{ Domestic fowl $(n=2)$} & 2 & 0 & 0 & H. wellingtoni & - \\
\hline & & 0 & 0 & 1 & H. wellingtoni & - \\
\hline \multirow[t]{2}{*}{ 10. Yala } & \multirow{2}{*}{$\begin{array}{l}\text { Domestic fowl }(n=1) \text {; } \\
\text { jungle fowl }(n=1)\end{array}$} & 0 & 1 & 0 & H. wellingtoni & - \\
\hline & & 1 & 2 & 0 & R. microplus & - \\
\hline Total & 32 & 24 & 27 & 18 & & 14 \\
\hline
\end{tabular}

Ticks were obtained from 10 locations in Thailand. The number of ticks tested and positive results for Coxiella bacteria are shown. Abbreviations: $\mathrm{M}$, male; $\mathrm{F}$, female; N, nymph; A., Amblyomma; H., Haemaphysalis; R., Rhipicephalus 


\section{Purification and sequencing of PCR products}

After PCR amplification and gel electrophoresis, DNA bands corresponding to positive amplification results were excised. Purified DNA samples (using Purification kit from Roche, Basel, Switzerland) were sent to the Ramathibodi Research Department (Ramathibodi Hospital, Bangkok, Thailand) for DNA sequencing. The results were analysed and compared with other DNA sequences from GenBank in the National Center for Biotechnology Information database (NCBI: https://blast.ncbi.nlm.nih.gov/Blast.cgi?PAGE_TYPE=BlastSearch).

\section{Phylogenetic analyses}

DNA sequences were edited and aligned with MEGA6 using ClustalW multiple sequence alignment algorithm. DNA sequences from this study, along with selected reference strains from GenBank, were used to construct a phylogenetic tree via Maximum Likelihood (Kimura 2-parameter model) and determining the confidence value for each branch of the phylogenetic tree with bootstrap analysis by using 1000 pseudoreplicates of the original alignment.

\section{Results and Discussion}

A total of 69 ticks collected from domestic and jungle fowl and Siamese firebacks belong to 3 genera: Haemaphysalis; Amblyomma; and Rhipicephalus (Table 1). The 51 adult ticks included $14 R$. microplus, $37 \mathrm{H}$. wellingtoni and the remaining 18 ticks were nymphs of $H$. wellingtoni $(n=$ 7), H. obesa $(n=5), H$. bispinosa $(n=3)$ and A. testudinarium $(n=3)$. The $16 S$ mDNA sequences of ticks were submitted to the GenBank database under the accession numbers MG865746 ( $H$. wellingtoni),

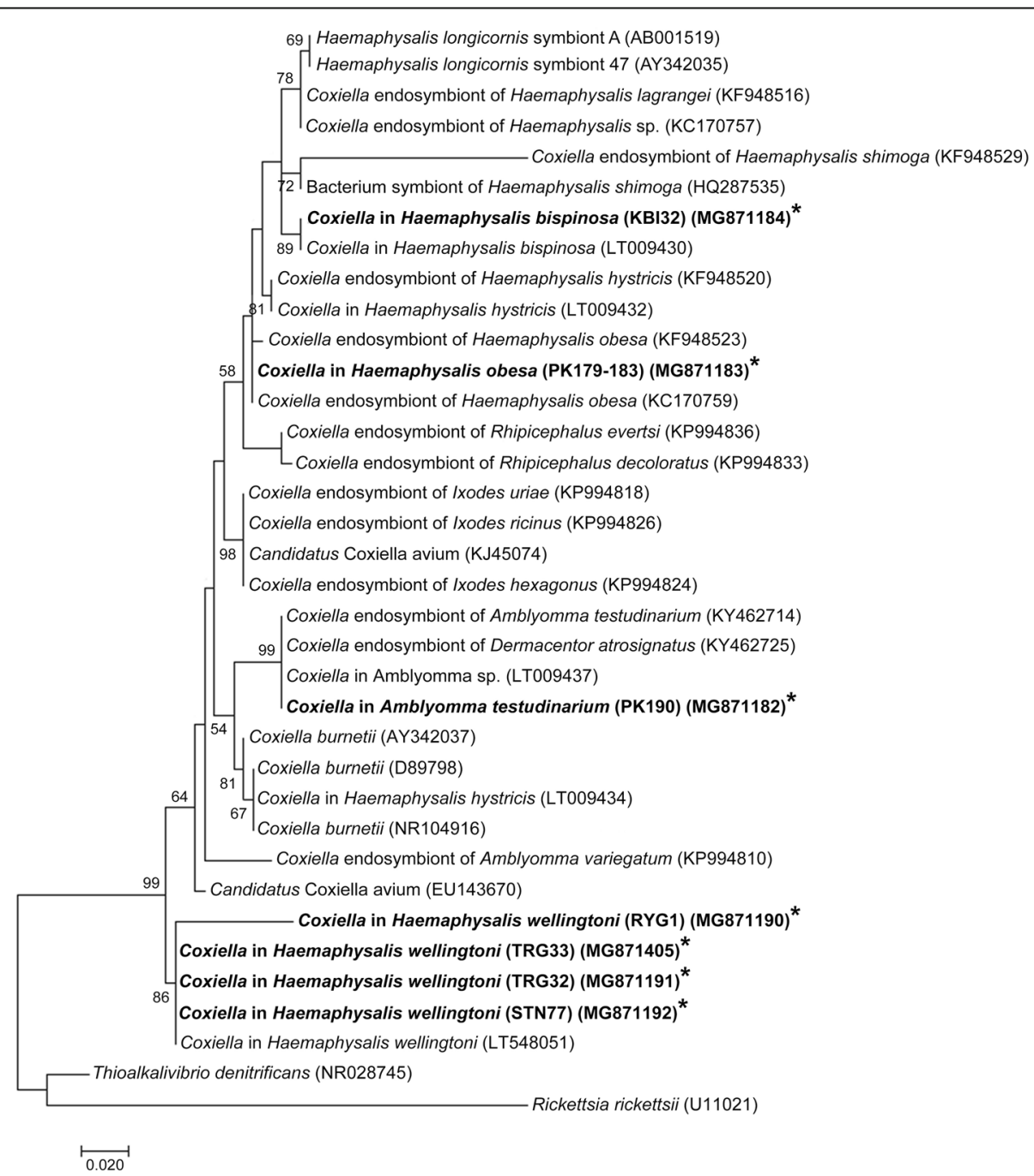

Fig. 1 Phylogenetic tree for Coxiella-like bacteria 16S rRNA gene sequences constructed with the Maximum Likelihood method using MEGA6 software. Bootstrap analysis was performed with 1000 pseudoreplicates. Rickettsia rickettsii was used as the outgroup. Coxiella-like bacteria isolates from this study are indicated in bold and with asterisks 
MG874025, MG910463 and MG874022 (H. obesa, H. bispinosa, and $A$. testudinarium, respectively). A total of 14 out of 69 ticks tested were positive for Coxiella bacteria, as defined by the amplification of $16 \mathrm{~S}$ rRNA sequences. Positive results were found in $H$. wellingtoni from Chumphon, Krabi, Rayong, Satun and Trang, $H$. obesa from Chaiyaphum, $H$. bispinosa from Krabi and $A$. testudinarium from Chaiyaphum (Table 1).

Coxiella bacteria-positive samples were sequenced, and a phylogenetic tree was constructed based on their analysis (Fig. 1). Coxiella DNA sequences were submitted to the GenBank database, including $H$. wellingtoni from Trang (TRG32 and TRG33), H. obesa and A. testudinarium from Chaiyaphum (PK179-183 and PK190), $H$. wellingtoni from Rayong (RYG1), H. wellingtoni from Satun (STN77) and H. bispinosa from Krabi (KBI32) (see Fig. 1 for accession numbers).

The phylogenetic analysis, based on the $16 \mathrm{~S}$ rRNA gene, showed that Coxiella bacteria from Haemaphysalis ticks of domestic fowl and Siamese firebacks were grouped with Coxiella bacteria of the same corresponding tick species previously reported (Fig. 1). In addition, the $16 S$ rRNA sequence of $A$. testudinarium of our study was in the same group with those reported by Nooroong et al. [3] and Khoo et al. [14] (Fig. 1).

Phylogenetic analyses of rpoB and groEL genes of Coxiella-like bacteria were also performed. The results are shown in Figs. 2 and 3. Most of Coxiella rpoB sequences from this study were in the same group and exhibited 8889\% identity with Coxiella-like endosymbiont of Argas reflexus (isolate Areflex2, GenBank: KY677983) and Coxiella endosymbiont of ticks of the genus Ixodes (GenBank: KP985313, KP985318 and KP985320) (Fig. 2). However, $r p o B$ gene sequences of Coxiella-like bacteria in $H$. wellingtoni from Trang (TRG33) clustered in a different clade and was closely related to Coxiella endosymbiont of Rhipicephalus sp. isolate (Tchien14; GenBank: KP985345; 96\% identity) (Fig. 2). The rpoB gene sequences of Coxiella bacteria detected in this study did not cluster together with those previously reported in the same tick species by Khoo et el. [14] (H. bispinosa and Amblyomma spp.). Instead they seemed to be clustering by their geographical distribution forming a Thai cluster (the present study) and a Malaysian cluster (data by Khoo et al. [14]). Coxiella groEL gene sequences detected in ticks from domestic fowl and Siamese firebacks from this study were clustered in the same clade (three sister groups) and exhibited about 89\% DNA sequence identity with "Candidatus Coxiella avium” from seabird ticks (GenBank: KJ459059) (Fig. 3).

Coxiella bacteria have been reported in several tick species, such as Rhipicephalus sanguineus (s.l.), Amblyomma americanum, Ixodes uriae and the soft tick O. rostratus $[1,2,15,16]$. In addition, Coxiellalike bacteria were also detected in Haemaphysalis ticks, such as $H$. lagrangei, $H$. obesa, $H$. shimoga and $H$. hystricis [3]. In the present study, the rate of

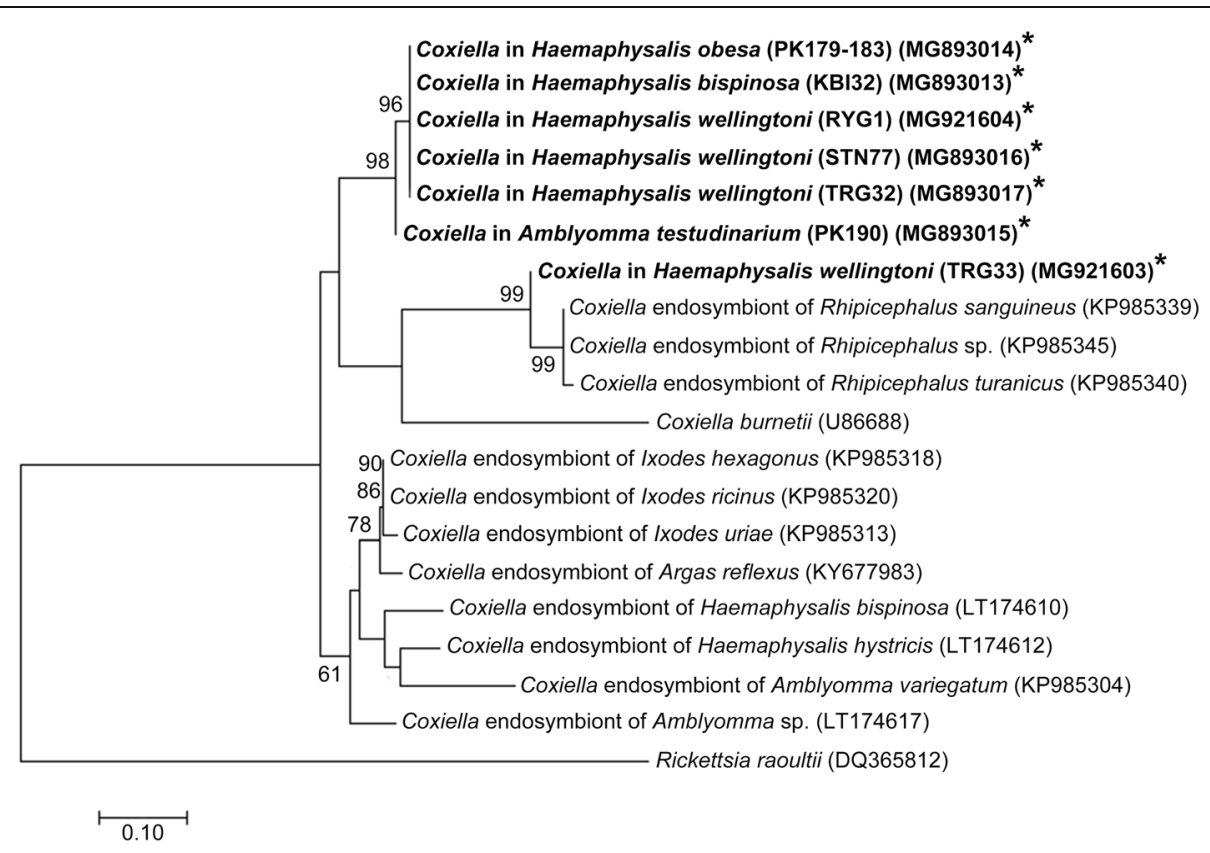

Fig. 2 Phylogenetic tree for Coxiella-like bacteria rpoB gene sequences constructed with the Maximum Likelihood method using MEGA6 software. Bootstrap analysis was performed with 1000 pseudoreplicates. Rickettsia raoultii was used as the outgroup. Coxiella-like bacteria isolates from this study are indicated in bold and with asterisks 


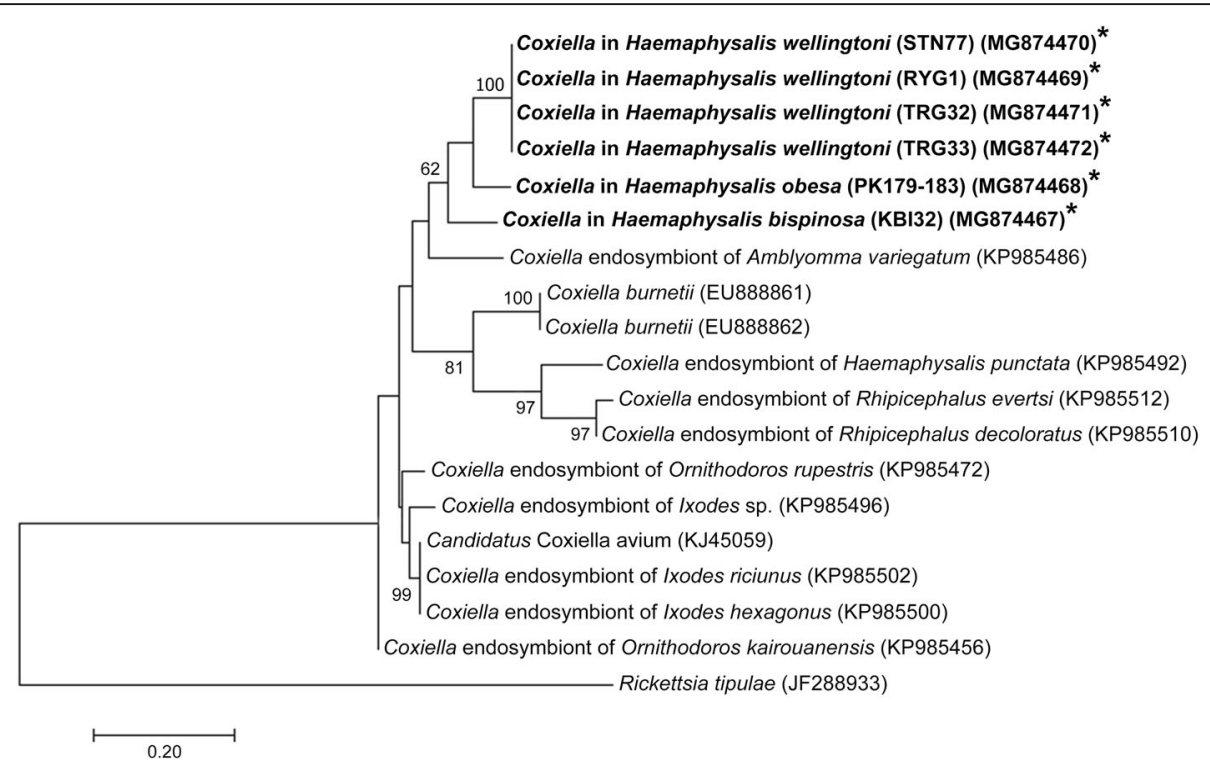

Fig. 3 Phylogenetic tree for Coxiella-like bacteria groEL gene sequences constructed with the Maximum Likelihood method using MEGA6 software. Bootstrap analysis was performed with 1000 pseudoreplicates. Rickettsia tipulae was used as the outgroup. Coxiella-like bacteria isolates from this study are indicated in bold and with asterisks

Coxiella-like bacteria in ticks collected from fowl was rather high because about $20 \%$ of ticks of the 4 species ( $H$. wellingtoni, $H$. bispinosa, $H$. obesa and $A$. testudinarium) were positive for Coxiella-like bacteria. Thus, our results seem to agree with those of Arthan et al. [4] who demonstrated that the prevalence was not dependent on tick species.

Analyses of rров sequences revealed that most of Coxiella-like bacteria exhibited $88-89 \%$ identity with Coxiella-like endosymbiont from Argas reflexus (isolate Areflex2). However, rpoB gene of Coxiella bacteria in $H$. wellingtoni from Trang (TRG33) was clustered in the different group in the phylogenetic analysis and related to Coxiella-like bacteria of Rhipicephalus sp. isolate Tchien $14 \mathrm{rpoB}$ gene, partial cds (96\% identity). This result may simply be indicative of a horizontal gene transfer event. Since only a small number of sequences is reported here, and only one with these characteristics is shown, it remains to be determined what is the real impact of this observation. The interesting point is that Coxiella rpoB sequences from different $H$. wellingtoni ticks belong to a different clade (even from the same tick species). The roles of these Coxiella-like bacteria in ticks and their fowl hosts are still unclear and needs further investigation.

\section{Conclusions}

To our knowledge, we found for the first time that Coxiella rpoB gene sequences from different $H$. wellingtoni ticks belong to two different clades and that rpoB sequence of the Coxiella bacteria detected in this study did not cluster together with those previously reported in the same tick species.

\section{Acknowledgments}

We thank the staff at Biodiversity Research Cluster, Department of Biology, Faculty of Science, Mahidol University, Thailand, for their technical assistance.

\section{Funding}

This research project is supported by Mahidol University and BDC PERDO (BDC-PG2-160008), Thailand.

\section{Availability of data and materials}

Data supporting the conclusions of this article are included within the article and its additional files. The DNA sequences of ticks (165 mDNA) were submitted to the GenBank database under the accession numbers MG865746 for H. wellingtoni adult, MG874025 for H. obesa nymph, MG910463 for H. bispinosa nymph and MG874022 for A. testudinarium nymph. Coxiella-like bacteria genes were submitted to GenBank as follows: Cox-16S rRNA (in H. bispinosa (KBI32: MG871184); in H. obesa (PK179-183: MG871183); in A. testudinarium (PK190: MG871182); in H. wellingtoni (RYG1: MG871190; TRG33: MG871405; TRG32: MG871191; STN77: MG871192). Coxiella in H. bispinosa (KBI32: MG871184); in H. obesa (PK179-183: MG871183); in A. testudinarium (PK190: MG871182); in H. wellingtoni (RYG1: MG871190; TRG33: MG871405; TRG32: MG871191; STN77: MG871192). Cox-groEL: Coxiella in H. bispinosa (KBI32: MG87467); in H. obesa (PK179-183: MG874468); in H. wellingtoni (RYG1: MG874469; TRG33: MG874472; TRG32: MG874471; STN77: MG874470). Cox-rpoB: Coxiella in H. bispinosa (KBI32: MG893013); in H. obesa (PK179-183: MG893014); in A. testudinarium (PK190: MG893015); in H. wellingtoni (RYG1: MG921604); in H. bispinosa (TRG33: MG921603; TRG32: MG893017; STN77: MG893016).

\section{Authors' contributions}

WT and AA planned and designed the study. WT, AA and SM carried out the majority of the laboratory and tick identification work. WK and PU performed phylogenetic analyses. WT and AA wrote the manuscript with advice from VB. All authors read and approved the final manuscript. 


\section{Ethics approval and consent to participate}

The study was carried out according to the license number U1-05257-2559 from NRCT, Thailand.

\section{Consent for publication}

Not applicable.

\section{Competing interests}

The authors declare that they have no competing interests.

\section{Publisher's Note}

Springer Nature remains neutral with regard to jurisdictional claims in published maps and institutional affiliations.

Received: 28 June 2018 Accepted: 5 December 2018

Published online: 27 December 2018

\section{References}

1. Almeida AP, Marcili A, Leite RC, Nieri-Bastos FA, Domingues LN, Martins J, et al. Coxiella symbiont in the tick Ornithodoros rostratus (Acari: Argasidae). Ticks Tick Borne Dis. 2012;3:203-6.

2. Duron $\mathrm{O}$, Jourdain $\mathrm{E}, \mathrm{McCoy} \mathrm{KD}$. Diversity and global distribution of the Coxiella intracellular bacterium in seabird ticks. Ticks Tick Borne Dis. 2014;5:557-63.

3. Nooroong P, Trinachartvanit W, Baimai V, Ahantarig A. Phylogenetic studies of bacteria (Rickettsia, Coxiella, and Anaplasma) in Amblyomma and Dermacentor ticks in Thailand and their co-infection. Ticks Tick Borne Dis. 2018;9:963-71.

4. Arthan W, Sumrandee C, Hirunkanokpun S, Kitthawee S, Baimai V, Trinachartvanit W, et al. Detection of Coxiella-like endosymbiont in Haemaphysalis tick in Thailand. Ticks Tick Borne Dis. 2015;6:63-8.

5. Angelakis E, Raoult D. Q fever. Vet Microbiol. 2010;140:297-309.

6. Madariaga MG, Rezai K, Trenholme GM, Weinstein RA. Q fever: a biological weapon in your backyard. Lancet Infect Dis. 2003;3:709-21.

7. Muramatsu Y, Usaki N, Thongchai C, Kramomtong I, Kriengsak P, Tamura Y. Seroepidemiologic survey in Thailand of Coxiella burnetii infection in cattle and chickens and presence in ticks attached to dairy cattle. Southeast Asian J Trop Med Public Health. 2014;45:1167-72.

8. Shivaprasad HL, Cadenas MB, Diab SS, Nordhausen R, Bradway D, Crespo R, et al. Coxiella-like infection in Psittacines and a Toucan. Avian Dis. 2008;52:426-32.

9. Ahantarig A, Malaisri P, Hirunkanokpun S, Sumrandee C, Trinachartvanit W, Baimai V. Detection of Rickettsia and a novel Haemaphysalis shimoga symbiont bacterium in ticks in Thailand. Curr Microbiol. 2011;62:1496-502.

10. Kauffman TS. A revision of the genus Aponomma Neuman, 1899 (Acarina: Ixodidae). PhD Thesis, University of Maryland; 1972.

11. Tanskul PL, Stark HE, Inlao I. A checklist of ticks of Thailand (Acari: Metastigmata: Ixodoidea). J Med Entomol. 1983;20:330-41.

12. Black WC, Piesman J. Phylogeny of hard- and soft-tick taxa (Acari: Ixodida) based on mitochondrial 165 rDNA sequences. Proc Natl Acad Sci USA. 1994;91:10034-8.

13. Duron O, Noël V, McCoy KD, Bonazzi M, Sidi-Boumedine K, Morel O, et al. The recent evolution of a maternally-inherited endosymbiont of ticks led to the emergence of the $\mathrm{Q}$ fever pathogen, Coxiella burnetii. PLoS Pathog. 2015;11:e1004892.

14. Khoo JJ, Lim FS, Chen F, Phoon WH, Khor CS, Pike BL, et al. Coxiella detection in ticks from wildlife and livestock in Malaysia. Vector Borne Zoonotic Dis. 2016;16:744-51.

15. Noda H, Munderloh UG, Kurtti TJ. Endosymbionts of ticks and their relationship to Wolbachia spp. and tick-borne pathogens of humans and animals. Appl Environ Microbiol. 1997;63:3926-32.

16. Jasinskas A, Zhong J, Barbour AG. Highly prevalent Coxiella sp. bacterium in the tick vector Amblyomma americanum. Appl Environ Microbiol. 2007;73:334-6.

\section{Ready to submit your research? Choose BMC and benefit from:}

- fast, convenient online submission

- thorough peer review by experienced researchers in your field

- rapid publication on acceptance

- support for research data, including large and complex data types

- gold Open Access which fosters wider collaboration and increased citations

- maximum visibility for your research: over $100 \mathrm{M}$ website views per year

At BMC, research is always in progress.

Learn more biomedcentral.com/submissions 